\title{
Policy sciences and democracy: a reexamination
}

\author{
Douglas Torgerson ${ }^{1}$
}

Published online: 24 July 2017

(C) Springer Science+Business Media, LLC 2017

The public, well, the dear public can be bamboozled with phrases.

-Harold D. Lasswell, $1924^{1}$

\section{The paradox of Policy Sciences}

Policy Sciences has, since the inception of the journal, been beset by an apparent paradox. Even though its keynote has been diversity, the journal has also been animated by a central theoretical orientation. The accent on diversity was already evident in E. S. Quade's inaugural editorial, which promised 'contributions reflecting all aspects of the policy sciences in all forms - think pieces, case studies, ideological essays, tirades, and historical surveys' (1970: 2). Yet, how can such diversity be congruent with a central theoretical orientation?

The paradox can be resolved if we recognize that the theoretical orientation which inspired the formation of the journal has a need for diversity at its core. This need for diversity-principally of perspectives and experiences-is notable in what Brunner and Willard have called, 'central theory' (2003: 4-8) in reference to the framework for the policy sciences conceived by Harold D. Lasswell. To reexamine here the relationship between policy sciences and democracy (cf. Dryzek and Torgerson 1993), we need to focus on key elements of that framework, on Lasswell's proposal for 'the policy sciences of democracy,' and on the condition, moreover, of the public.

$\overline{1}$ Quoted in Torgerson (1990: 349; cf. 341n. 9 and corresponding text).

Editor of Policy Sciences, 1992-1995.

Douglas Torgerson

dtorgerson@trentu.ca

1 Trent University, Peterborough, ON, Canada 
The need for diversity is evident in the three particular features of the framework that Lasswell highlights: it stresses context, it encourages a multiplicity of methods, and it is guided by a concern to address practical problems (1971: xiii). Of these, context poses a particular need for diversity. That is because Lasswell sees an ongoing project of contextual mapping as crucial to the identity and conduct of the policy sciences (ibid.: 3 ). As we look to that contextual project, we can further recognize that Lasswell did not conceive the affirmation of democracy merely as a matter of arbitrary preference: rather, on his account, contextuality constitutes an internal connection of the policy sciences to democracy.

\section{Contextual orientation}

The need for a diversity of perspectives and experiences-together with a multiplicity of methods - is pronounced in a project of contextual mapping. In aiming to achieve an explicit 'contextual orientation' (Lasswell 1971: 156; cf. Torgerson 1985), inquiry begins with an image of 'self-in-context' that, at least implicitly, is an inescapable feature of everyone's practical experience in the world (1971: 155). Deliberate efforts at contextual mapping, however, throw into question implicit assumptions and images in order to revise, develop and refine contextual understandings. The project of contextual mapping aims to gradually create 'a sense of wholeness' that locates details in terms of a 'total configuration' (1935: 12-13).

That effort, for Lasswell, depends upon the 'efficacy of insight,' conceived in terms of the emancipatory logic of psychoanalysis (1956: 114). The aim, at one level, is to achieve 'liberation' and 'freedom' by undoing through insight the rigidity of psychological fixations and attachments that constrain individual rationality and imagination. There is thus a necessary focus on the 'self,' but since the self, in Lasswell's view, is always also a self-incontext, attention must turn as well to both cultural and historical levels.

With respect to culture, a key problem is that the 'obvious,' as being conventionally taken for granted, places its own constraints on judgment, rationality and imagination. So the task is to throw the obvious into question in a way that makes ongoing critical attention to it inescapable (Lasswell 1930: 250). For that purpose, psychoanalysis—as traditionally practiced-is inadequate, and its logic must be adapted to cultural and social levels of 'critique' (Lasswell 1971: 158). Such critique would need to actively entertain ideas and possibilities that are deemed unconventional from the perspective of prevailing 'ideology' (Lasswell 1961: 112).

To gain orientation to the ever-changing historical context, Lasswell recommended the elaboration of 'developmental constructs,' scenarios involving the 'continuum' of 'past, present, and future' (1935: 4; also see Torgerson 2007b: 15-21, 2013). Developmental constructs were to pay attention to specific conditions and trends; but they were also unavoidably speculative, could vary in terms of whether they were probable or desirable, could potentially have the effect of self-fulfilling or self-denying prophecies, and were emphatically to exclude mere wishful thinking. Lasswell offered two diametrically opposed developmental constructs. One was his famous idea of the 'garrison state,' later reformulated as the 'garrison-police state,' which he presented as a warning of an undesirable future prospect (1941b, 1948: 222). The other was progress toward a 'democratic commonwealth,' the suggestion of a desirable future (1948: 148). 
Underlying these two developmental constructs, however, was another, more basic one. Here Lasswell drew attention to the key importance of experts, or specialists, in the development of modern society. It was thus that he advanced the idea of a 'permanent revolution of modernizing intellectuals' (1965). The garrison state signaled the advent of 'specialists on violence,' whereas he saw a democratic commonwealth as reliant upon experts adhering to the 'principal value goal' of 'enlightenment about the policy process and its interaction with the social context' (1974: 181). It is in this connection that Lasswell advances his idea of a policy sciences profession that, requiring contextual orientation, seeks to attain a 'distinctive identity' (1971: 120). That achievement depends upon a 'quest' for identity involving individuals who 'loosen the bonds of the culture into which they are born by becoming aware of it' and who collectively initiate 'key symbols of identity,' which break with 'current stereotypes' (1958b: 193-194).

A project of contextual mapping requires more than individual effort, and is thus dependent upon collective institutions of inquiry and enlightenment-principally, an emerging policy sciences profession. Lasswell did not imagine that it would be easy to establish a policy sciences profession with the kind of commitment and contextual orientation that he advocated. There was the general problem, which he recognized early in his career, that 'professional training' typically produces 'self deception rather than self analysis' (1930: 37). In promoting a policy sciences profession, moreover, he saw that the 'pitfalls' were 'numerous' and that 'many initiatives' could be expected to 'fall short' (1971: 132). Working in 'arenas of power,' professionals find it imperative to learn 'the conditions of survival' while 'coming to terms with ... the typically oligarchical structure of internal politics' (ibid. 125). Commitment to enlightenment is especially challenged by 'circumstantial' pressures that arise 'when truth is exposed to the threats and temptations of power' (Lasswell 1974: 177).

In an insightful examination of the 'professional insecurities' that beset those seeking a career in the policy sciences, Brunner and Willard locate the source of much of the trouble, and much of the remedy, in Lasswellian central theory (2003; cf. Brunner 1991). 'Conventional practices' confront the aspiring professional not only with unsettled and ambiguous career advancement criteria; such practices, by accentuating specialization and fragmentation, are at odds with the focus on integration in central theory. Brunner and Willard draw attention to the difficult process of 'emancipation' — or 'freedom' by way of 'insight' (2003: 33) — and point to the challenge of advancing 'human dignity' (ibid.: 24). 'The task' in addressing both professional work and professional insecurities, they maintain, 'is to map the particular context, to orient oneself in the context mapped, and to reconsider both as events unfold' (4). By focusing primarily at an individual and psychological level, however, their discussion does not offer commensurate attention to the collective level where, for Lasswell, 'agencies of enlightenment' are crucial in contending with the threats and temptations of power (1958a: 97). A commitment to human dignity entails a commitment, moreover, to the policy sciences of democracy, which Lasswell recognized as 'controversial' (1948: 119).

Here we can understand how, in a project of contextual mapping, there is an internal connection with a commitment to democracy. This connection is neither logical nor necessary (and hence remains consistent with the principle of ethical non-cognitivism), but is one that comes from practice. It arises, at least as a distinct tendency, according to Lasswell, from the very practice of achieving a 'creative orientation' to context (1935: 13): 'Policy scientists who are committed to the free man's commonwealth find it difficult to believe that anyone who applies a fully contextual approach can stop short of making a similar commitment' (Lasswell 1968: 182; cf. 1971: 41-43; 1958a). For Lasswell, a 
commitment to human dignity and freedom is also, in political terms, a commitment to democracy: 'So far as law, government, and politics are concerned, the goal of human dignity (or freedom) unmistakably includes democracy, or the sharing of power in the community decision process' (Rubenstein and Lasswell 1966: 8).

\section{Whatever happened to democracy?}

'Democracy appears victorious and, with it, so do the policy sciences of democracy' (Dryzek and Torgerson 1993: 127). A quarter of a century ago that statement could plausibly be made, especially if it was understood that this appearance had less to do with developments within the policy sciences than with the fact that, for 'the first time in history, just about everyone who matters, anywhere, is a democrat - at least when it comes to the public justification of their programs, if not the reality of their actions' (ibid.). Indeed, 'if we scratch the surface of the symbolism,' the reality 'soon appears problematic, in the policy sciences no less than elsewhere' (ibid.). This meant that there was 'less an accomplishment to be celebrated than a project to be pursued' (136).

Today, we are familiar with concerns about a 'democratic deficit' in supposedly democratic countries. Similarly, Helen Ingram, Peter de Leon, and Anne Schneider have recently argued that the 'fundamentals of democracy are not being achieved even in Western industrialized nations where democracy is supposed to be most embedded' (2016: 176). Pointing to a conspicuous inattention to democracy in current policy frameworks, moreover, they call democracy the 'elephant in the corner' while proposing, in contrast, an approach that is explicitly 'democracy-centered' (ibid.: 175, 186). A 'neglect of democracy,' they note, is evident in that 'few public policy studies even mention democracy (or its absence) and certainly do not use it as a criterion in evaluating policy' (176). Bringing democracy back into the picture would require active support for democratic values-by, for example, combatting discrimination against marginalized people, involving all relevant perspectives in policy considerations, and encouraging the participation of citizens (ibid.). Ingram, de Leon, and Schneider do observe that in the late 1940s Lasswell announced 'the policy sciences of democracy' (177), but they add that ensuing developments have lacked both the conceptual richness and the central commitment to democracy he envisioned.

As Lasswell promoted the policy sciences of democracy during the period after World War II, liberal democracy had gained ascendancy in the industrially advanced countries of the West. This ascendancy became the implicit backdrop to the advent of a 'policy orientation' in the social sciences (Lasswell 1951b), and critics have portrayed Lasswell's commitment to democracy as little more than a form of 'democratic elitism' meant to protect the liberal democratic status quo (e.g., Bachrach 1967). One such criticism has acknowledged, however, that Lasswell's idea of democracy could be viewed as a forerunner to current notions of democracy as depending upon 'discussion, debate, and deliberation'-though only if he is read 'selectively and programmatically' (Farr et al. 2008: 30). If we give serious attention to Lasswell's idea of democracy at a conceptual level, however, we find that such an approach to democracy-far from being marginal to his idea-is actually central. ${ }^{2}$

\footnotetext{
${ }^{2}$ See the criticisms by Farr et al. (2006, 2008), together with the apt rejoinder by Brunner (2008). Both sides of this debate address Lasswell's work at the level of his practice, as well as conceptually. That is a promising connection, but deserves to be probed further - and should not, in any case, distract from the particular significance of the conceptual level (see Torgerson 2015: 43n. 4 and corresponding text).
} 
As Lasswell introduces his project of 'the policy sciences of democracy' (Lasswell 1948: 118ff.), he takes a decisive step away from the liberal democratic conception of democracy as simply a form of government by treating democracy further as a social form. Lasswell thereby calls for the 'progressive democratization of society,' requiring 'the continual reconstruction of whatever practices stand in the way of democratic personality and polity' (ibid: 148; cf. Macpherson 1972, 1977). The 'conception of democracy' that Lasswell explicitly advances, is one 'of a network of congenial and creative interpersonal relations' (1948: 110), and it is one, moreover, wherein 'the citizen will maintain some degree of active and informed participation in public affairs' (ibid.: 150). As a notable proviso, though, Lasswell states with evident approval the 'maxim' that 'shared power and respect (and enlightenment) depend upon a very considerable dispersion of wealth throughout the community' (149).

Conceptualizing democracy as a type of society as well as a type of government, Lasswell points to what has more recently become familiar in terms of the idea of a democratic deficit. He identifies in 'even democratic regimes' a failure to develop 'procedures' that meet 'the need of giving everyone a voice in what seems to concern them' (1948: 190). Meeting this need means sharing power not only regarding government, but also more broadly in society. Lasswell thus points to 'choices which were formerly governed by calculations of economic advantage' being 'transformed ... into power decisions...' (ibid.: 191) — especially, the 'undermining of democracy when people are subject to arbitrary exercises of power...' (192): 'The corporation that decides to close down a given plant in the community may inflict severe deprivations upon workers who have invested in homes, paid taxes for municipal services, and developed community life' (ibid.). In Lasswell's view, this problem arises because of 'the silent transformation of genuinely competitive markets (where such existed) into monopoly-political arenas' (213).

The 'contextual principle' is, for Lasswell, the key to removing 'ideological blinders from our eyes' (1948: 220). That principle supports 'detachment' from an over-emphasis on 'this or that doctrine' (ibid.: 221), helping us to guard against taking 'too seriously' such common terms as 'socialism' and 'capitalism' (222). 'Capitalism,' he argues in particular, has undergone a transformation making it 'a political organization' that has 'concealed its nature by speaking the language of "business," "competition," "free enterprise" and the like' (214). 'Falsely calling themselves "businessmen" (rather than politicians),' 'monopoly-politicians' seek to 'invoke the symbol of "business" to line up what is left of genuinely competitive business behind them in an effort to prevent the application of democratic methods of control to their arena of arbitrary power' (ibid., italics in original).

Lasswell did not claim that the 'democratic commonwealth' he proposed was likely, only that it was a possible historical prospect worth pursuing. Progressive democratization had a chance in the mixed socio-economic system characteristic of modern society, but the specter of oligarchy also loomed, especially in the form of a 'garrison state.' In fact, 'chronic crisis' could result—and here Lasswell pressed his idea further-in 'the regimentation of a garrison-police state': 'Only antisocialist and antibusiness elements in society stand to gain from chronic crises. They are the potential rulers of a world concentration camp...' (1948: 222).

Although Lasswell saw a policy sciences profession as important to progressive democratization, he did not imagine that profession standing outside the forces of history and simply directing the shape of things to come. The role he saw was a much more modest one of seeking ways to enhance the rationality of the policy process and to strengthen democratic participation. In A Pre-View of Policy Sciences (1971), he developed the idea that a policy sciences profession should foster broader participation in public policy. Lasswell explicitly called for the 'encouragement of continuous general participation' 
(ibid.: 117). The point was to advance widespread involvement in 'the shaping and sharing of power' (44). He accordingly proposed that experts be allocated to the service of all those involved in 'public controversy' - the aim being to enhance the rationality of decision processes by drawing attention to matters that 'would otherwise be neglected' (121). He suggested that 'passive or episodic' media audiences could become 'active and continuing participants in the policy processes,' including both 'the conduct of research' and 'systematic appraisal' (117).

Lasswell particularly proposed the notable idea of the power-sharing 'prototype' (1971: 70-71), as remarkably illustrated in The Sharing of Power in a Psychiatric Hospital, written with the psychiatrist Robert Rubenstein (Rubenstein and Lasswell 1966). Henry Kariel, a political theorist at times sharply critical of conventional 'policy science' work, nonetheless perceived in that book 'a dramatic illustration of how social science can creatively restructure a prevailing system of power' by initiating 'a democratic forum for sharing power' (Kariel 1969: 137-138). Yet, this initiative was not, for Lasswell, an intervention into larger power dynamics in order to directly encourage continuous general participation. The initiative was contained, rather, within a limited power context disposed to enabling it. That relatively narrow focus prompts a question: how does such an initiative-and, indeed, how does the policy sciences profession itself-relate to a larger context of power: particularly to the condition therein of the public?

\section{The condition of the public}

Populist trends current in Europe and the United States, often coupled with markedly authoritarian appeals, have arisen in a context characterized less by considered, civil discourse in the public sphere, than by bombastic rhetoric punctuated by sound bytes, tweets, and instant images - all animating anew 'the paranoid style' in politics. That well-known term of Richard Hofstadter did not indicate a psychopathological diagnosis, but a way to designate, as an 'international phenomenon,' the deployment of 'paranoid modes of expression by more or less normal people' $(1964: 7,1)$. To the extent that such trends prevail, the populace tends to become receptive to the appeals of the authoritarian-populist demagogue. The context, at the same time, tends to become unreceptive to expertise, even dismissive of it - and hardly conducive to the policy sciences of democracy. However, there is nothing new about the public being in a problematic condition; and we can, in fact, recall an earlier such period, one that includes initial intimations of Lasswell's policy sciences.

Progressive hopes for a happy marriage of democracy and science fell on hard times with the phenomenal rise of mass propaganda during World War I. As 'democratic romanticism' collapsed (Lasswell 1927a: 4), a debate ensued over the condition of the public. Walter Lippmann's Public Opinion (1922) stressed the limits of public enlightenment-along with the inadequacy of any democratic theory based upon it-and prescribed instead the remedy of mobilizing experts to deliver on 'the promise of expertise' (Goodwin 1995). John Dewey, in response, allowed that Lippmann had put his finger on 'the fundamental problem of democracy'; yet Dewey dissented in favor of promoting public enlightenment: 'The enlightenment of public opinion still seems to me to have priority over the enlightenment of officials and directors' (Dewey 1922: 344).

It was in the context of the disillusionment with public opinion advanced by Lippmann that Lasswell undertook his work on propaganda-which he saw as shaping 'collective attitudes by the manipulation of significant symbols' (1927b: 627). We might recognize 
some vacillation by Lasswell between the positions of Lippmann and Dewey. Yet already in his Ph.D. thesis, Propaganda Technique in the World War (completed in 1926), he noted the capacity of propaganda to 'bamboozle' the public (1927a: 5), and he saw as well that disillusionment with public opinion was accompanied by an increasingly 'dictatorial habit of mind' (ibid.: 4). Lasswell's hope, in contrast, was that 'illuminating' propaganda technique would help to 'bring much into the open that is obscure,' thereby undercutting the surreptitious power of propaganda $(222) .^{3}$

In Psychopathology and Politics, Lasswell nonetheless expressed concern that 'the public may be dissolved into a crowd' in which hostility toward dissent is aroused (1930: 192). There he laid stress on the importance of a 'politics of prevention' and a key role for 'political psychiatrists,' along with a need for the education of social administrators and social scientists to include 'prolonged self-scrutiny' so as to foster a more objective outlook (201; cf. ch. 1). Lasswell later saw in the propagandistic exploitation of 'emotional conflicts' and the elicitation of hostile impulses what would emerge as the most extreme form of authoritarian populism (1933: 384), and he would also underscore the risks of irrationality accompanying 'mass emancipations' (1935: 77).

In an implicit response to Lippmann, Lasswell would go on to suggest a path indicated by the title of his book Democracy through Public Opinion (1941a), which could be read as a contribution avant la lettre to the literature on deliberative democracy. He proposes a 'new way to talk' (ibid.: 80), a manner of informed discourse that, averse to propagandistic and demagogic incitement, is facilitated by the professional role of the 'clarifier' (89-93). In first announcing the policy sciences of democracy, moreover, he shifted away from his earlier focus and held that 'elevating the level ... of the whole community' was more important than 'the specialized training of the few' (1948: 148). He remained concerned about 'the dubious and dangerous expectation of democracy through mass revolution' (ibid.: 212), yet he nonetheless came, in the mid-1960s, to recognize a vital commitment in the 'great social movements of our time': that calling 'for full participation as equals in the affairs of the community by the disadvantaged' (Rubenstein and Lasswell 1966: 2).

Confidence in the capability of social scientists to develop a consensual map of context to guide their work and its application to public affairs is a recurring belief in Lasswell, already expressed during the earliest period of his career (see Torgerson 1987: 11). When he came to propose the policy sciences of democracy, he further suggested that the education of the citizenry be informed by social science, even in the critical form of 'the dissemination of insight on a vast scale to the adult population' (1948: 148-149, 196). With his account of contextual orientation and his proposal for continuous general participation in A Pre-View of Policy Sciences, the idea of a consensual map took the form of an 'antidote to bureaucratism and oligarchy': 'The essential principle is that a picture of the self-in-context can be made available to participants at every level of formal authority from top to bottom in every hierarchical arrangement' (1971: 119-120, italics in original). Here and elsewhere, Lasswell's accent remained on the singular, on establishing 'a unified framework of experience' (1963: 142). It was in his posthumously published The Signature of Power, however, that Lasswell decisively moved beyond his accent on consensus: 'The scholars from various cultural and ideological backgrounds currently differ in interpreting the dynamics of

\footnotetext{
3 Horwitz's critique of Lasswell as 'the master propagandist' (1962), although distinguished by the quality of its research, relies overmuch on Lasswell's early theme of 'control' and fails to recognize the theme of 'emancipation,' which is accentuated later (e.g., Lasswell 1951a: 524; cf. Torgerson 1985: 241-244). In contrast to control through propaganda, an emancipatory interest in enlightenment extols the pedagogical or therapeutic. By the same token, perplexities do persist for any critical approach committed to democracy (see Torgerson 2015: 31-36).
} 
society' (1979: 63). Much as Lasswell had earlier proposed for professionals 'undogmatic access to inclusive versions of reality' (1971: 156), the point he advances here is to present to the public not a single map, or chart, or picture, but 'alternative versions' of social dynamics — with the explicit aim of promoting 'more disciplined judgment' (1979: 63).

The quest for a creative contextual orientation is critical in the specific sense that it manifests an interest in emancipation (cf. Habermas 1971: 197-198; Torgerson 1985: 241-244). Nonetheless, much of the reception of 'policy science' has, given the overall background of conventional approaches, tended to treat that term as indicative of a distinctly uncritical posture: 'Attuned to a settled, predefined political reality, trusting it,' Kariel said in 1972, 'policy science remains effortlessly on the side of accredited interests' (106). The 'practitioners' of policy science, he adds, are 'not disposed to interfere with established definitions of reality' (ibid.). Kariel's observation and Laurence Tribe's contemporaneous critique of 'policy science' as technocratic 'ideology' (1972) are notable among developments anticipating the emergence of an explicitly critical approach to policy studies from the 1980s onward.

Critical policy studies turned a suspicious eye toward technocratic tendencies in the policy field, seeking to puncture the balloon of an overinflated pretense to knowledge while exposing the inadequacy of a methodological orientation that tended to obscure its own shortcomings (Fischer et al. 2015). The point was not to abandon inquiry, or expertise, but to appreciate limits and to suggest, as a remedy, an emphasis on deliberation, participation, and the significance of disputes among experts. Although points of convergence with the critical and democratic features of Lasswell's approach were recognized (e.g., Torgerson 1985; Bobrow and Dryzek 1987: 172-174; Dryzek 1990: ch. 6), critical policy studies proceeded with a stronger, direct critique of conventional approaches (yet, cf. Lasswell 1955). The concern was not simply about technocracy as the rule of experts, but about expert roles in supporting broader oligarchic power relations. This concern was addressed through overtly controversial proposals for forms of deliberative democracy (Dryzek 2000) or for participatory expertise and governance (Fischer 1992, 2006). In the context of a 'politics of expertise' (Fischer 1990), moreover, practitioners influenced by the outlook of critical policy studies tended to proceed with 'a demystification of professional expertise' (Schön 1983: 345), identifying less as professionals than as 'counterprofessionals'-even though, as aptly pointed out by Donald Schön, they could not entirely escape what they questioned: 'Experts tend to behave like experts' (ibid.: 342).

Charles E. Merriam, Lasswell's mentor at the University of Chicago, published his New Aspects of Politics in 1925, during the post-WWI debate over the condition of the public (cf. Karl 1974: 98-99). There he not only advanced an outline for a science of politics that would be both behavioral and applied; he also had recourse, strikingly, to the old Aristotelian virtue of phronēsis. Merriam rendered that idea as 'political prudence'- 'the conclusions of experience and reflection regarding the problems of politics: wisdom that does not reach the state of science, yet has its own significance' (1925: 163). For Merriam, political prudence was not the exclusive province of intellectuals —or 'savants,' as he called them-but needed development by the citizenry as a whole, thereby enhancing the 'general level of judgment and insight' (ibid.: 179). Not only was such an enhancement necessary for 'prudent political conduct' in governing a polity; it was necessary as well if serious ideas were to be taken seriously (ibid.). The 'quality' of conclusions reached by social science needed recognition, moreover, if it were to be effectively utilized (178). Merriam also raised concerns about the role of intellectuals themselves if they could not engage in dialog, but set to wrangling and obfuscation among themselves. For him, that would signal the need for their education to foster more 'balanced judgment' (165). 
As with Merriam-as also with Dewey (see Torgerson 1995: 231-233)—judgment plays a central, even if less obvious, role in Lasswell's proposal for the policy sciences of democracy. Explicitly invoking Merriam's account of political prudence, Lasswell maintains that political practice demands 'a "positional sense"; the maxims of prudence require "good judgment” for successful application' (Lasswell and Kaplan 1950: xxii). Contextually informed inquiry, he once noted, itself calls for 'political orientation' (Lasswell 1935: 215), which would evidently be a particular requisite for the policy scientist, understood as a 'participant observer of events who tries to see things as they are' (1971: 3). Contextual mapping culminates, moreover, in a creative 'act' of orientation (1935: 13) that encourages the use of one's 'capabilities for imagination and judgment' (1971: 156).

By recalling the rise of propaganda and the collapse of democratic romanticism during and after World War I, we may be in a better position to judge the current predicament as democratic hopes face the emergence of authoritarian populism. If an approach to policy now aspires to be both critical and democratically committed, what course needs to be taken? Posing that question points beyond the domain of professionalism to the larger context of the public - particularly, to the plurality of emergent publics.

Lasswell's whole approach to the policy sciences was informed by a basic developmental construct that saw the rise of intellectuals — and the significance of skill—as a crucial event in the emergence of advanced industrial societies. Whether or not Lasswell overestimated the historical importance of intellectuals, including that of policy specialists, he did not claim that they constituted the central force of historical development. He did not see policy scientists somehow rising above the conditions and trends of history to guide it on their own. That was clear already in his 1941 elaboration of the of the 'garrison state' developmental construct, wherein he indicated that — come the garrison state—a role could still be played by social scientists in preserving 'as many values' of democracy as they could (1941b: 467). Lasswell's main point is simply that that the roles of policy professionals are bound to be, in some way, important. Indeed, critical policy studies proceeds with much the same rationale.

The policy sciences of democracy depended, in any case for Lasswell, on a profession committed to promoting enlightenment. At the same time, he stressed the image of a common identity among policy scientists, not fully addressing the conflicts among experts that animate the politics of expertise (cf. Torgerson 1985: 254-256, 1986). It was when he came to confront the problem of clear disagreements among social scientists that he recognized the need to present the public with a plurality of perspectives, not a single account or orienting map.

Can the policy sciences ultimately integrate such a diversity of viewpoints within a single frame of reference? That is doubtful because, as Lasswell himself emphatically maintained, the distinctions necessary for inquiry arise from 'the context of culture' itself (1971: 17-18; cf. Torgerson 1992: 229-230), so that-if disagreements are grounded in culture - they can be expected to persist, amid a plurality of voices. That might seem to suggest the persistence of conflict and an end to discussion, even to the point of violence: 'I have no words: My voice is in my sword' (Macbeth 5.8.8-9). Yet disagreement, indeed conflict, can remain along with the achievement of a modus vivendi, even concurrence on policy proposals. ${ }^{4}$ The key, as ever, is context, and what also crucially matters is whether

\footnotetext{
4 A notable example is the Scientific Panel for Sustainable Forest Practices in Clayoquot Sound, British Columbia, which (due to political exigencies) included experts in both modern science and traditional indigenous knowledge. Although the two sets of experts did not come to agree on epistemological principle, they did achieve mutual respect and a consensus on policy recommendations (see Torgerson 2003: 128-131).
} 
there are mutual efforts to overcome misunderstanding-despite real grievances-or whether conflicts are intensified and exploited through demagoguery.

In recognizing the importance of the 'great social movements of our time,' Lasswell also acknowledged another importance of plurality. The plural perspectives of such movements have served as points of reference in critical policy studies. Movement activities, moreover, are not simply instrumental, but also constitute spaces for discourse and enlightenment-emphatically not as a single, homogeneous public, but a plurality of 'emergent publics'.5 In specific policy controversies, emergent publics may retain or develop their own experts, who certainly do not reject the value of expertise. These experts have the capacity, rather, to enhance the quality and practicality of expertise by highlighting what 'would otherwise be neglected' (to recall Lasswell's words) while also contributing to public enlightenment and democratization.

The prospects for policy inquiry that is both critical and democratically committed cannot, in the end, be separated from the condition of the public. Indeed, the key problem facing such inquiry is precisely what Dewey, well aware of the difficulties posed by propaganda (1927: 348), ${ }^{6}$ famously called the problem of the public. Professionals-or counterprofessionals - cannot simply look within, but need to consider the roles they might play to enhance the quality of public judgment and discourse, especially given the deleterious impact of authoritarian-populist demagoguery. To find a key guiding principle, we might thus look back to what Dewey in 1927 had to say in The Public and its Problems (ibid.: 365, italics in original): 'The essential need ... is the improvement of the methods and conditions of debate, discussion, and persuasion: That is the problem of the public.'

\section{References}

\section{For chronological clarity, works (except translations) are cited and listed by date of initial publication.}

Bachrach, P. (1967). The theory of democratic elitism: A critique. Boston: Little, Brown.

Bobrow, D., \& Dryzek, J. S. (1987). Policy analysis by design. Pittsburgh: University of Pittsburgh Press. Brunner, R. D. (1991). The policy movement as a policy problem. Policy Sciences, 24(1), 65-98.

Brunner, R. D. (2008). The policy scientist of democracy revisited. Policy Sciences, 41(1), 3-19.

Brunner, R. D., \& Willard, A. R. (2003). Professional insecurities: A guide to understanding and career management. Policy Sciences, 36(1), 3-36.

Dewey, J. (1922). Review of Walter Lippmann, Public Opinion. In J. A. Boydston (Ed.), John Dewey: The middle works, Vol. 13 (pp. 337-344). Carbondale and Edwardsville: Southern Illinois University Press, 1983.

Dewey, J. (1927). The public and its problems. In J. A. Boydston (Ed.), John Dewey: The later works, Vol. 2 (pp. 235-372). Carbondale and Edwardsville: Southern Illinois University Press, 1984.

Dryzek, J. S. (1990). Discursive democracy. Cambridge: Cambridge University Press.

Dryzek, J. S. (2000). Deliberative democracy and beyond. Oxford: Oxford University Press.

\footnotetext{
5 See Torgerson (2007a), where Bahktin's 'dialogue' and Rancière's 'disagreement' are addressed.

${ }^{6}$ Dewey indicates that the discussion of propaganda requires the perspective of a specialist, quite possibly having in mind Lasswell, who had completed his $\mathrm{Ph} . \mathrm{D}$. thesis on the topic the previous year. Lasswell, in fact, had met Dewey for 'a rather extended conversation' while in high school and, as a graduate student, was 'occasionally able to talk' with Dewey at the home of George Herbert Mead (Marvick 1977: 17, 21-22). In any event, Lasswell would later designate his conception of the policy sciences as an 'adaptation of the general approach to public policy that was recommended by John Dewey and his colleagues in American pragmatism' (1971: xiv).
} 
Dryzek, J. S., \& Torgerson, D. (1993). Editorial: Democracy and the policy sciences-A progress report. Policy Sciences, 26(3), 127-137.

Farr, J., Hacker, J. S., \& Kazee, N. (2006). The policy scientist of democracy: The discipline of Harold D. Lasswell. American Political Science Review, 100(4), 579-587.

Farr, J., Hacker, J. S., \& Kazee, N. (2008). Revisiting Lasswell. Policy Sciences, 41(1), 21-32.

Fischer, F. (1990). Technocracy and the politics of expertise. Newbury Park, CA: Sage.

Fischer, F. (1992). Participatory expertise: Toward the democratization of policy science. In W. N. Dunn \& R. M. Kelly (Eds.), Advances in policy studies since 1950 (pp. 351-376). New Brunswick, NJ: Transaction Press.

Fischer, F. (2006). Participatory governance as deliberative empowerment: The cultural politics of discursive space. The American Review of Public Administration, 36(1), 19-40.

Fischer, F., Torgerson, D., Durnová, A., \& Orsini, M. (2015). Introduction to critical policy studies. In F. Fischer, D. Torgerson, A. Durnová, \& M. Orsini (Eds.), Handbook of critical policy studies (pp. 1-24). Cheltenham: Edward Elgar Publishing.

Goodwin, C. (1995). The promise of expertise: Walter Lippmann and the policy sciences. Policy Sciences, 28(4), 317-345.

Habermas, J. (1971). Knowledge and human interests (J. Shapiro, Trans.). Boston: Beacon Press.

Hofstadter, R. (1964). The paranoid style in American politics, Harper's. November 1-10. Accessed 6 June 2017. https://harpers.org/archive/1964/11/the-paranoid-style-in-american-politics/.

Horwitz, R. (1962). Scientific propaganda: Harold D. Lasswell. In H. J. Storing (Ed.), Essays on the scientific study of politics (pp. 225-304). New York: Holt, Rinehart and Winston.

Ingram, H., de Leon, P., \& Schneider, A. (2016). Public policy theory and democracy: The elephant in the corner. In B. G. Peters \& P. Zittoun (Eds.), Contemporary approaches to public policy (pp. 175-200). London: Palgrave Macmillan.

Kariel, H. S. (1969). Open systems: Arenas for political action. Itasca, IL: F.E. Peacock Publishers.

Kariel, H. S. (1972). Commentary on Lane's paper. In J. C. Charlesworth (Ed.), Integration of the social sciences through policy analysis (pp. 103-108). Philadelphia: American Academy of Political and Social Science.

Karl, B. D. (1974). Charles E. Merriam and the study of politics. Chicago: University of Chicago Press.

Lasswell, H. D. (1926). Review of Walter Lippmann, The Phantom Public. American Journal of Sociology, 31(4), 533-535.

Lasswell, H. D. (1927a). Propaganda technique in the World War. New York: Peter Smith, 1938.

Lasswell, H. D. (1927b). The theory of political propaganda. American Political Science Review, 21(3), $627-631$.

Lasswell, H. D. (1930). Psychopathology and politics. Chicago: University of Chicago Press, 1977.

Lasswell, H. D. (1933). The psychology of Hitlerism. The Political Quarterly, 4(3), 373-384.

Lasswell, H. D. (1935). World politics and personal insecurity. New York: The Free Press, 1965.

Lasswell, H. D. (1941a). Democracy through public opinion. Menasha, WI: George Banta Publishing.

Lasswell, H. D. (1941b). The garrison state. American Journal of Sociology, 46(4), 455-468.

Lasswell, H. D. (1948). Power and personality. New York: W.W. Norton, 1976.

Lasswell, H. D. (Ed.). (1951a). Democratic character. In The political writings of Harold D. Lasswell (pp. 465-525). Glencoe, IL: The Free Press.

Lasswell, H. D. (1951b). The policy orientation. In D. Lerner \& H. D. Lasswell (Eds.), The policy sciences (pp. 3-15). Stanford: Stanford University Press.

Lasswell, H. D. (1955). Current studies of the decision process: Automation versus creativity. The Western Political Quarterly, 8(3), 381-399.

Lasswell, H. D. (1956). Impact of psychoanalytic thinking on the social sciences. In L. D. White (Ed.), The state of the social sciences (pp. 84-115). Chicago: University of Chicago Press.

Lasswell, H. D. (1958a). Clarifying value judgment: Principles of content and procedure. Inquiry, 1(4), 87-98.

Lasswell, H. D. (Ed.). (1958b). Postscript. In Politics: Who gets what, when, how (pp. 181-211). New York: Meridian Books.

Lasswell, H. D. (1961). The qualitative and the quantitative in political and legal analysis. In D. Lerner (Ed.), Quantity and quality (pp. 103-116). New York: The Free Press of Glencoe.

Lasswell, H. D. (1963). The future of political science. New York: Atherton Press.

Lasswell, H. D. (1965). The world revolution of our time: A framework for basic policy research. In H. D. Lasswell \& D. Lerner (Eds.), World revolutionary elites (pp. 29-96). Cambridge, MA: The MIT Press.

Lasswell, H. D. (1968). Policy sciences. International Encyclopedia of the Social Sciences, 12, 181-189.

Lasswell, H. D. (1971). A pre-view of policy sciences. New York: American Elsevier. 
Lasswell, H. D. (1974). Some perplexities of policy theory. Social Research, 41(1), 176-189.

Lasswell, H. D. (1979). The signature of power. New Brunswick, NJ: Transaction Books.

Lasswell, H. D., \& Kaplan, A. (1950). Power and society: A framework for political inquiry. New Haven: Yale University Press.

Lippmann, W. (1922). Public opinion. New York: The Free Press, 1965.

Macpherson, C. B. (1972). The real world of democracy. Toronto: CBC Publications.

Macpherson, C. B. (1977). The life and times of liberal democracy. Oxford: Oxford University Press.

Marvick, D. (1977). Introduction: Contexts, problems and methods. In D. Marvick (Ed.), Harold D. Lasswell on Political Sociology (pp. 1-71). Chicago: University of Chicago Press.

Merriam, C. E. (1925). New aspects of politics. Chicago: University of Chicago Press, 1931.

Quade, E. S. (1970). Editorial: Why policy sciences? Policy Sciences, 1(1), 1-2.

Rubenstein, R., \& Lasswell, H. D. (1966). The sharing of power in a psychiatric hospital. New Haven: Yale University Press.

Schön, D. (1983). The reflective practitioner: How professionals think in action. New York: Basic Books.

Torgerson, D. (1985). Contextual orientation in policy analysis: The contribution of Harold D. Lasswell. Policy Sciences, 18(3), 241-261.

Torgerson, D. (1986). Between knowledge and politics: Three faces of policy analysis. Policy Sciences, $19(1), 33-59$.

Torgerson, D. (1987). Political vision and the policy orientation: Lasswell's early letters. In Paper presented at the annual meetings of the American Political Science Association, Chicago, September 3-6.

Torgerson, D. (1990). Origins of the policy orientation: The aesthetic dimension in Lasswell's political vision. History of Political Thought, 11(2), 339-351.

Torgerson, D. (1992). Editorial: Priest and jester in the policy sciences-Developing the focus of inquiry. Policy Sciences, 25(3), 225-235.

Torgerson, D. (1995). Policy analysis and public life: The restoration of phronēsis? In J. Farr, J. S. Dryzek, \& S. T. Leonard (Eds.), Political science in history: Research programs and political traditions (pp. 225-252). Cambridge: Cambridge University Press.

Torgerson, D. (2003). Democracy through policy discourse. In M. A. Hajer \& H. Wagenaar (Eds.), Deliberative policy analysis (pp. 113-138). Cambridge: Cambridge University Press.

Torgerson, D. (2007a). Policy discourse as dialogue: Emergent publics and the reflexive turn. Critical Policy Studies, 1(1), 1-17.

Torgerson, D. (2007b). Promoting the policy orientation: Lasswell in context. In F. Fischer, G. J. Miller, \& M. S. Sidney (Eds.), Handbook of public policy analysis (pp. 15-28). London: Taylor and Francis.

Torgerson, D. (2013). Reflexivity and developmental constructs: The case of sustainable futures. Journal of Environmental Policy and Planning, 15, 1-15.

Torgerson, D. (2015). Harold D. Lasswell and critical policy studies: The threats and temptations of power. In F. Fischer, D. Torgerson, A. Durnová, \& M. Orsini (Eds.), Handbook of critical policy studies (pp. 27-46). Cheltenham: Edward Elgar Publishing.

Tribe, L. H. (1972). Policy science: Analysis or ideology? Philosophy \& Public Affairs, 2(1), 66-110. 